\title{
VERSUCH \\ EINER PRAKTISCHEN HAMLET - KRITIK.
}

\section{Theater- nnd verlegermanuskripte.}

Wie kompliziert die Hamlet-frage sein mufs, ergibt sich aus der tatsache, dafs wir es nicht mit einem einzigen, sondern mit drei ganz verschiedenen Hamlet-texten zu tun haben. Wenn auch die verschiedenheiten zwischen den beiden jüngeren texten, der quartausgabe von 1604 und der folioausgabe von 1623, im vergleich zu den verschiedenheiten, die zwischen jedem dieser beiden texte und der ältesten quartausgabe von 1603 bestehen, nicht so bedeutend sind, so bleiben sie nichtsdestoweniger rätselhaft. Schon lange vor der erst im jahre 1823 erfolgten entdeckung jener ältesten ausgabe hatte man freilich die für die kritik unleugbar vorhandene schwierigkeit einfach dadurch aus der welt zu schaffen gesucht, dals man aus den beiden differierenden texten sich einen sogenannten normaltext verfertigte, aber dieses verfahren war offenbar mehr bequem als verständig. Immerhin hat man sich lange bei diesem normaltext beruhigt; er liegt fast allen untersuchungen über Hamlet $\mathrm{zu}$ grunde. $\mathrm{Da}$ jener erst in neuerer zeit aufgefundene älteste und von dem normaltext völlig verschiedene text den frieden der kritik bedenklich zu stören drohte, so suchte man den eindringling zunächst nach möglichkeit zu diskreditieren. Man sprach von diesem ältesten text nie anders als von der "gefälschten, unvollständigen" ausgabe. Aber diese bezeichnung ist nur dann gerechtfertigt, wenn man die beiden anderen ausgaben ohne weiteres zu "originalen und vollständigen" stempelt. An und für sich ist die älteste Hamlet-ausgabe genau so vollständig wie jeder 
ındere Shakespeare-text, und an und für sich hat sie auch renau so viel und genau so wenig autorität wie die übrigen iusgaben der Shakespeare-dramen. Aber weil nun eben einmal ler normaltext allgemeine giltigkeit erlangt hatte, mulste jener älteste text sich die anerkennung seiner existenz erst erkämpfen; und man muls zugeben, dals er, wenn auch langsam, mit der zeit immer mehr an boden gewonnen hat. Schon werden stimmen laut, die überhaupt an der existenz "gefälschter" ausgaben zweifeln (s. Proelss). Andrerseits hat man einige vorzüge dieser ältesten ausgabe nach und nach immer deutlicher erkannt, und Dowden sagt:

For my own part, repeated perusals have satisfied me that Shakespeare's hand can be discerned throughout the whole of the truncated and travestied play of 1603 .

(The Arden Shakespeare, Intr. p. XVIII.)

Die kritik mufs also unbedingt auch mit dieser ältesten ausgabe rechnen, auch wenn dadurch das problem fast unlösbar zu werden scheint. Es handelt sich nämlich jetzt nicht nur darum, wie sich die quartausgabe von $1604 \mathrm{zu}$ der ausgabe in der folio von 1623 verhält (schon ein äufserst schwieriges problem!), sondern vor allem auch darum, wie sich die grolsen unterschiede zwischen der ältesten ausgabe von 1603 und jenen beiden andern erklären lassen. Natürlich wäre es das einfachste anzunehmen, der dichter habe sein werk zweimal umgearbeitet, so dafs also die ausgabe von 1604 eine umarbeitung der ausgabe von 1603 und jene von 1623 wiederum eine umarbeitung derjenigen von 1604 darstellte. Aber schon die oberflächlichste vergleichung macht eine derartige theorie unmöglich. Wenn die worte III 2, $413 \mathrm{ff}$.:

Let me be cruel, not unnatural:

I will speak daggers; those sharp words being spent,

To do her wrong my soul shall ne'er consent

in $Q_{2}$ lauten:

Let me be cruel, not unnatural:

I will speak daggers to her, but use none;

My tongue and soul in this be hypocrites;

How in my words soever she be shent,

To give them seals never, my soul, consent -

so ist es ohne weiteres klar, dals wir es hier nicht mit einer umarbeitung, d. h. einer verbesserung, sondern mit einer verstümmelung zu tun haben. Man lese wie Hunter (New Shake- 
speare Illustrations, II 254) über diese stelle entsetzt ist. Wie kann Hamlet überhaupt nur an so etwas denken! Hunter schliefst seine bemerkungen mit den worten:

Hamlet a matricide would have become instantly an object of universal odium. In fact, the truth cannot and ought not to be concealed that, popular as this play is, not in England only, but all the world over, there are parts in it which seem quite at variance with the ordinary mode of thinking of its author.

Man vgl. auch Widgery in Harness Prize Essays 1880, s. 164/5. Der verfasser der stelle in $Q_{2}$ dachte offenbar an nichts andres als den augenblicklichen effekt; um der antithese speak use willen, liels er charaktere, handlung und situation unberücksichtigt. Möglich wäre es auch, dafs er zu seiner änderung im letzten grund durch eine falsche betonung veranlarst worden ist; er las vielleicht speák daggers, während es heifsen muIs speak dággers, mit starkem nachdruck auf daggers. Ebenso ist es eine verstümmelung und nicht eine umarbeitung, wenn es III 3,93 zwar in $Q_{1}$ heilst:

Then trip him that his heels may kick at heaven

And fall as low as hell -

in $Q_{2}$ aber:

Then trip him, that his heels may kick at heaven,

And that his soul may be as damned and black

As hell, whereto it goes.

Die einheit und grolsartigkeit des bildes ist hier jammervoll zerstört; an die stelle eines plastischen ausdrucks ist die sinnlose behauptung getreten, dals die hölle verdammt und schwarz sei. Um schliefslich auch noch ein ganz einfaches beispiel zu erwähnen, so wird niemand leugnen können, daIs inapproved in I 1, 96 ein verständliches wort ist, dagegen unimproved, wie $Q_{2}$ hat, unklar. Diese beispiele lassen sich leicht verzehn- ja verzwanzigfachen; sie liefern den unumstöIslichen beweis, dafs die unterschiede zwischen den einzelnen Hamlet-texten nicht durch die hypothese der „umarbeitung" erklärt werden können. An dieser stelle nun drängt sich von selbst ein umstand auf, der meines erachtens in der Shakespeare-kritik noch nicht genügend gewürdigt worden ist, nämlich die tatsache, dafs die dramen elisabethanischer zeit nicht auf originalmanuskripte, sondern auf theatermanuskripte zurückgehen. Der dichter verkaufte damals sein stück 
an eine theatergesellschaft, in deren uneingeschränkten besitz diese stücke übergingen. Die schauspieler hatten also nicht nur die möglichkeit, sondern sogar das recht, zu ändern was und soviel sie wollten. Ich habe diesen punkt schon mehrmals erörtert und will hier nur noch eine stelle aus Halliwell's Memoranda on Hamlet, p. 65 f. anführen :

In old plays alterations of every kind were made for the convenience of the actors. In a manuscript of one which I have lately seen, written in 1601 , there are alterations for actors with the observation, - "these alterations the one or the other, you may chuse the better". In another manuscript drama of the same date the writer, after giving two forms of a speech, quaintly adds to one, - "if this shall not be so fitt for the understanding, it being uncouth to the audience, the other alteration may well serve". Sometimes the alterations were made in reference to the theatre in which the play was to be acted. Attached to some altered speeches in another dramatic manuscript of 1603 is the note, - "thus for some or for Powles".

Wir besitzen noch rechnungen, nach denen dichter für zusätze, eingelegte szenen oder ganze umarbeitungen beliebter dramen bezahlt worden sind. Wir müssen also zunächst annehmen, daIs allen elisabethanischen dramen, die wirklich aufgeführt worden sind (es gab auch damals schon buchdramen!), nicht originalmanuskripte, sondern immer nur theatermanuskripte zu grunde lagen. Theatermanuskript $=$ originalmanuskript + zusätze! Es ist ohne weiteres klar, dafs in einem beliebten stück jeder schauspieler bemüht war, seine rolle nach möglichkeit zu vergrölsern. Wenn sich nun ein verleger eines solchen dramas bemächtigte, so konnte er selbstverständlich nichts anderes abdrucken, als das theatermanuskript, denn ein originalmanuskript gab es nicht mehr; das originalmanuskript hatte sich in das theatermanuskript verwandelt. Sobald aber wiederum ein verleger durch den druck dieses dramas geld verdiente, suchte ihn sein konkurrent zu übertrumpfen; dies geschah am einfachsten dadurch, dals man das gedruckte drama völlig umarbeiten liefs und diese umarbeitung zum original stempelte. Auf diese weise verwandelte sich das theatermanuskript in das verlegermanuskript. Verlegermanuskript $=$ (originalmanuskript + zusätze $) \times$ umarbeitung! Hatte das originalmanuskript drei bogen, so hatte das theatermanuskript vielleicht fünf, das verlegermanuskript aber gar zehn! Ich glaube, dals sich die möglichkeit der existenz solcher 
theater- und verlegermanuskripte nicht wird leugnen lassen. Haben sie aber existiert, dann scheint das verhältnis der drei Hamlet-texte zu einander mit einem schlag klar. Die beiden jüngeren texte, die quartausgabe von 1604 und der foliotext von 1623 sind nämlich so ungeheuer weitschweifig, dals man unter keinen umständen annehmen kann, unser drama sei damals genau in dieser form wirklich aufgeführt worden. Schon Steevens (Var. $\boldsymbol{E} d$. vol. VII) hat darum erklärt:

The degree of credit due to the title-page that styles the manuscript from which the quartos 1604 and 1605 were printed, the 'true and perfect copy' may also be disputable. I cannot help supposing this publication to contain all Shakespeare rejected, as well as all he supplied. By restorations like the former, contending booksellers or theatres might have gained some temporary advantage over each other, which at this distance of time is not to be understood. The patience of our ancestors exceeded our own, could it have out-lasted the tragedy of Hamlet as it is now printed; for it must have occupied almost five hours in representation.

Und Seymour in seinem trefflichen buch „Remarks on Shake-

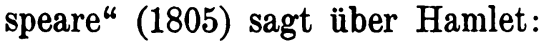

This play appears to have been from Shakespeare's time to our own, inclusive, the most popular of his productions; and yet there are few among them more clouded by impurities, and disfigured by interpolation, in which the plot is so indeterminate, the conduct so inconsistent, and the principal and favourite person of the story, in morals, action, and behaviour, so irregular and censurable .... The estimation in which Hamlet was held induced the early publishers to boast that it had been 'enlarged to almost as much again as it was'; and to serve their purpose, they have given us all that either the author or the players had from time to time been adding to the mass, without rejecting a line of what, doubtless, the poet himself had superseded in this prolix tragedy."

Man wird also $\mathrm{zu}$ dem vorläufigen schlufs gedrängt, dafs $Q_{2}$ und $F$ von verlegermanuskripten gedruckt worden sind, $Q_{1}$ aber von einem theatermanuskript. Denn wenn $Q_{1}$ auch eine menge guter stellen enthält, die sich weder in $Q_{2}$ noch in $F$ finden, so fehlt es andererseits doch auch in $Q_{1}$ nicht an schlechten und einander widersprechenden partieen.

\section{Problem und methode.}

Das problem, mit dem sich die Hamlet-kritik bisher hauptsächlich beschäftigt hat, nämlich das problem des verhältnisses 
der drei Hamlet-texte zu einander, wäre also jetzt vorläufig gelöst, und zwar durch die einfache annahme, dafs theater- und verlegermanuskripte existiert haben. Aber der kritik wird jetzt ein weit wichtigeres problem vorgelegt. Es handelt sich jetzt darum festzustellen, ob sich innerhalb der Hamlet-überlieferung vielleicht noch das original erkennen läIst. Für jeden fall ist es klar, dafs, falls dieses original noch erhalten ist, es nur in einem theatermanuskript gesucht werden kann, denn das verlegermanuskript stellte eine völlige umarbeitung dar, d. h. also während das theatermanuskript nur zusätze zum original enthielt, hat man im verlegermanuskript ganze stellen einfach ausgestrichen und durch andere ersetzt. Ein beispiel einer solcher „umarbeitung“ für die zwecke des verlegers bietet uns der text der zweiten quartausgabe von Romeo and Juliet (s. Unser Shakespeare, heft III u. IV). Sollte uns also ein günstiges geschick den echten Hamlet aufbewahrt haben, so können wir denselben höchstens in der quartausgabe von 1603 entdecken. Wir müssen demnach in der ältesten quartausgabe das echte von dem unechten scheiden. Aber ist das überhaupt möglich? Man ist in der wissenschaft gegen alle derartigen versuche mit recht äufserst mifstrauisch geworden, denn die subjektivität des einzelnen spielt hierbei eine zu grofse rolle, als dals man auch nur ein einigermalsen sicheres resultat erwarten könnte. Aber läIst sich diese subjektivität denn wirklich auf keine weise ausschalten? Worin besteht diese subjektivität, und wie zeigt sie sich? Wir sind subjektiv, wenn wir mit einer vorgefalsten meinung an unseren stoff herangehen und darin etwas finden, was wir vorher selbst in den stoff hineingelegt haben. Unsere subjektivität äufsert sich dann naturgemäls darin, dals wir uns mit unsrer kritik immer nur gerade soweit hervorwagen, als dies unbeschadet unsrer vorgefafsten meinung geschehen kann. Um ein bild zu gebrauchen: Eine statue, die in einer form gegossen worden ist, bildet mit dieser form zusammen einen unförmlichen klumpen. Wer nun mit der absicht, eine statue hervorzubringen, an diesem klumpen herummeifseln würde, der würde wohl ganz bald eine statue herausbringen, aber eine statue, die mit der wirklich in diesem klumpen verborgenen statue, vielleicht nicht die geringste älnlichkeit hat. Das einzig richtige verfahren in diesem fall ist, daIs man nicht den 
meifsel, sondern den hammer nimmt und so lange und so fest auf den klumpen losschlägt, bis die form abspringt und den kern freigibt. Wir dürfen also nicht an die statue, sondern nur an das schlagen denken; haben wir doch die ruhige zuversicht, dals, wenn in dem klumpen wirklich eine statue verborgen ist, unsere schläge dieser statue nur nützen, d. $h$. sie freilegen werden. Also nicht theorie, hypothese, sondern rücksichtslosigkeit, konsequenz ist vonnöten! Wollen wir in der ältesten Hamlet-ausgabe das echte von dem unechten scheiden, so dürfen wir uns durchaus kein bild von diesem echten machen. Wir haben keine andere aufgabe, als den uns vorliegenden text aufs sorgfältigste und eindringlichste $\mathrm{zu}$ kritisieren. Sollte als resultat unsrer kritik zufällig ein einheitlicher text übrig bleiben, so wäre damit auf praktischem wege der nachweis erbracht, dafs die älteste Hamlet-ausgabe wirklich nach einem theatermanuskript gedruckt worden ist; denn wir hätten dann das theatermanuskript in einen einheitlichen kern (= originalmanuskript) und zusätze zerlegt. Das problem also ist: scheidung des echten vom unechten. Jene methode aber, die jede subjektivität völlig ausschliefst, ist keine andere als die der erbarmungslosen kritik.

\section{Bemerkungen zu dem nachstehenden text.}

Der text, den ich hier dem leser zur prüfung vorlege, ist das resultat einer solchen „erbarmungslosen“ kritik. "Erbarmungslos", das soll heifsen, dafs ich an diesen ältesten Hamlet-text herangegangen bin, ohne die absicht, und oft ohne jede hoffnung, darin einen bleibenden kern zu entdecken. Ich habe mich weder durch die rücksicht auf die resultate der bisherigen kritik, noch durch die autorität des namens Shakespeare abhalten lassen, das was ich an dem überlieferten text als schlecht erkannte, auch wirklich als schlecht zu bezeichnen. Nach jahrelanger arbeit, während derer ich oftmals zu der überzeugung $\mathrm{kam}$, dals ich, abgesehen von dem vorteil beständiger kritischer übung, kein praktisches resultat erzielen werde, hat sich mir endlich doch der nachstehende text als der einheitliche kern der quartausgabe von 1603 enthüllt. Dieser neue text ist also eine genaue wiedergabe des ältesten Hamlet-textes, nur dafs alle als schlecht erkannten stellen weggelassen worden sind. Ich habe versucht, meine gründe 
für die entfernung der einzelnen stellen schriftlich $z \mathfrak{u}$ fixieren Ich begann mit einer vergleichung der quartausgabe von 1604 mit dem text der folio. In einem zweiten abschnitt verglich ich den aus diesen beiden ausgaben hergestellten normaltext mit dem ältesten text von 1603 und besprach die einzelnen von der kritik vorgebrachten theorieen über das verhältnis dieser texte $z \mathfrak{u}$ einander. Da sich als resultat dieser beiden vergleichungen ergab, dafs nur in dem ältesten text wirklich gute stellen zu finden seien, so wurde in einem dritten abschnitt dieser älteste text noch einmal für sich aufs genauste geprüft. In einem vierten abschnitt sollte dann die einheit des aus diesen kritiken sich ergebenden textes dargetan werden. Der grölste teil dieser ausführlichen darlegung ist bereits druckfertig, aber es gilt nun zunächst einmal, dals der neue, hier vorgelegte text auch wirklich als eine einheit erkannt werde. So scharfsinnig unsre wissenschaft auch in bezug auf einzelheiten ist, so fehlt es ihr doch häufig an dem blick für das ganze, und es dürfte deshalb wohl das richtige sein, daIs der leser zunächst einmal durch keine spezialuntersuchung von der prüfung und betrachtung der einheit dieses neuen textes abgelenkt werde. $\mathrm{Da}$ aber andrerseits jeder leser die eine oder andere ihm liebgewordene stelle hier vermissen wird, so will ich mit zwei beispielen kurz auf die art meiner kritik hinweisen.

Man wird in dem neuen text vergebens den berühmten monolog To be suchen. Warum dieser monolog weder zu Hamlet, noch in die handlung, noch in die situation palst und warum er auch von sprachkritischem standpunkt aus sinnlos ist, darüber könnte man ein ganzes buch schreiben. Es sei deshalb hier nur erwähnt, dals hervorragende kritiker (Lichtenberg, Hebler, Fr. Th. Vischer) uns warnen, diesen monolog so hoch $\mathrm{zu}$ bewerten, wie seine berühmtheit $\mathrm{zu}$ fordern scheint, und dafs ein mann von so augenscheinlicher gesundheit und nüchternheit des urteils, wie Goldsmith, diesen monolog sogar einen "haufen absurditäten" genannt hat. In dem aufsatz über "Metaphern", der sich in einer serie ähnlicher aufsätze befindet, die vom Juli 1761 bis Januar 1763 in der zeitschrift British Magazine erschienen sind, spricht er lange über unsern monolog. Ich zitiere aus diesem abschnitt nur folgendes: 
The soliloquy in Hamlet, which we have so often heard extolled in terms of admiration, is, in our opinion, a heap of absurdities, whether we consider the situation, the sentiment, the argumentation, or the poetry .... In order to support this general charge against an author so universally held in veneration, whose very errors have helped to sanctify his character among the multitude, we will descend to particulars, and analyze this famous soliloquy .... If we consider the metaphors of the soliloquy, we shall find them jumbled together in a strange confusion. If the metaphors were reduced to painting, we should find it a very difficult task, if not altogether impracticable, to represent with any propriety outrageous Fortune using her slings and arrows, between which, indeed, there is no sort of analogy in nature. Neither can any figure be more ridiculously absurd than that of a man taking arms against a sea exclusive of the incongruous medley of slings, arrows, and seas, justled within the compass of one reflection. What follows is a strange rhapsody of broken images of sleeping, dreaming, and shifting off a coil, which last conveys no idea that can be represented on canvass. A man may be exhibited shuffling off his garments, or his chains; but how he should shuffle off a coil, which is another term for noise and tumult, we cannot comprehend. Then we have long-lived calamity, and time armed with whips and scorns; and patient merit spurned at by unworthiness; and misery with a bare bodkin going to make his own quietus, which at best is but a mean metaphor. These are followed by figures, sweating under fardels of burthens, puzzled with doubts, shaking with fears, and flying from evils. Finally, we see resolution sicklied o'er with pale thought, a conception like that of representing health by sickness; and a current of pith turned away so as to lose the name of action, which is both an error in fancy, and a solecism in sense. In a word, this soliloquy may be compared to the aegri somnia, and the tabula cujus vanae fingentur species.

Ich habe also niemals gefragt: Kann Shakespeare so etwas gesagt haben? (denn an und für sich kann Shakespeare alles gesagt haben!), sondern nur: Hat das, was hier steht, für uns moderne menschen einen völlig einwandfreien sinn?

Das auffallendste an dem neuen text dürfte aber wohl der umstand sein, dals die rolle des geistes so aufserordentlich gekürzt ist. Der geist erscheint nur in zwei, nicht in drei szenen, und - was das wichtigste ist - er redet überhaupt nicht. Es ist allgemein bekannt, wie richtig Lessing im elften stück der Hamburgischen dramaturgie darauf hingewiesen hat, dals das erscheinen des geistes in Hamlet natürlich ist, $d . \mathbf{h}$. dals unser verstand gegen dieses auftreten eines gespenstes keinerlei einwendungen machen kann.

"Shakespeares gespenst kommt wirklich aus jener welt; so dünkt uns. Denn es kommt zu der feierlichen stunde, in der schaudernden 
stille der nacht, in der vollen begleitung aller der düsteren, geheimnisvollen nebenbegriffe, wann und mit welchen wir, von der amme an, gespenster $z u$ erwarten und zu denken gewohnt sind."

Lessing legt allen nachdruck auf die art, wie der geist bei Shakespeare erscheint, denn er will zeigen, wie töricht die art ist, in der Voltaire den geist des Ninus auf die bühne kommen läIst. Am anfang des zwölften stücks erwähnt Lessing freilich noch, dals der geist bei Shakespeare im gegensatz zu dem bei Voltaire eine handelnde person sei, an deren schicksal wir anteil nehmen, aber er geht auf diesen umstand nicht näher ein, und er hätte dies auch nicht tun können, ohne auch an Shakespeare's gespenst grofse albernheiten zu entdecken. Schon daIs ein "gespenst" gleichzeitig eine „handelnde person“ sein soll, ist etwas, das - um Lessings eigene worte zu gebrauchen - "wider alles herkommen, wider alle gute sitte unter den gespenstern ist", und „alles, was die illusion hier nicht befördert, störet die illusion". Lessing sieht es als ein grunderfordernis an, dals der dramatische dichter uns täuscht, dals er also nur solche dinge auf die bühne bringt, die wir auch wirklich glauben können. Er rechtfertigt Shakespeare, indem er sagt: „Der same, gespenster zu glauben, liegt in uns allen." Und es ist in der tat durchaus nicht auffällig, dais leute in dem wahn leben, sie hätten ein gespenst gesehen. Das ist uns allen schon einmal passiert. Also dafs Marzellus und Horatio, und schliefslich auch Hamlet, den geist des verstorbenen Dänenkönigs zu sehen glauben, das ist an und für sich vor dem schärfsten verstand durchaus gerechtfertigt. Etwas ganz anderes ist es aber, dafs tatsächlich ein solcher geist vorhanden sein soll, dafs er seine wirklichkeit durch sein sprechen unzweifelhaft dartut! Lessing hätte seinen satz, dals wir alle an gespenster glauben, noch etwas präziser fassen können: Wir glauben nur an gespenster, die in einer gewissen entfernung bleiben, aber nicht an gespenster, die sich uns anvertrauen. Kein gebildeter, ja nicht einmal ein kind, wird an ein gespenst glauben, mit dem es sich unterhalten kann. Gewils kann es vorkommen, dals wir auch „gespensterhafte laute" hören, aber dann sind diese laute unverständlich und schaurig. Ein geist aber, der meine muttersprache spricht, stellt sich mit mir auf die gleiche stufe, ich mufs ihn als wirklich ansehen, d. $h$. als einen menschen und nicht als ein gespenst. Mit dem augen- 
blick, wo der geist redet, ist alle illusion unwiderbringlich dahin, und die handlung wird grotesk, albern, kindisch. Der nachdenkende leser wird ohne zweifel eine menge gründe entdecken, die ihm dartun werden, dals diese gespensterreden sinnlos sind. Das schlimmste aber ist, dafs durch diese plumpe effekthascherei ungebildeter schauspieler - denn nur diesen können diese gespensterreden ihre entstehung verdanken der aufbau der handlung zerstört wird, wie man dies aus der folgenden geistreichen darlegung eines leider nur zu wenig bekannten Shakespeare-kritikers entnehmen kann:

"Es ist garnicht paradox und man wird mich auch nicht mifsverstehen, wenn ich nach dem vorausgeschickten den ausspruch wage, der Hamlet scheine mir unter den werken des dichters zwar in aller welt als das gedankenreichste und tiefsinnigste, aber blofs dramatisch betrachtet als das ungenügendste, $j a$ in der tat als das schlechteste. Denn es geht ein sinn- und herzzerreifsender zwiespalt durch die anlage des ganzen stücks. Grofsartiger hat die poesie nie etwas entworfen als den anfang des Hamlet. Vom ersten wort auf der terrasse ist der hörer, sei er wer er wolle, gefesselt; das gespensterwesen ist das populärste motiv, an das sich die moderne tragödie halten kann; aber auch unsre ubberbildung, auch der lederne rationalismus wird dem eindruck der so sinnreich motivierten vorstellung des gespensterglaubens in dieser szene nicht widerstehen können; oder wer es kann, der möge getrost aller poesie den rücken kehren; denn für ihn ist sie nicht. Dieses geistergeheimnis zieht sich in mächtiger steigerung durch den ganzen ersten akt; selbst die zwischengeschobene repräsentationsszene macht in ihrer steifen gemessenheit nur den nötigen kontrast gegen den wirklichen ernst jenes geisterspuks, und die szene, wo die beiden geschwister, die Hamlet so nahe stehen, sich ihr herz eröffnen, macht ebenfalls den rührendsten eindruck der familien-innigkeit, die der zerrissenheit des prinzen zur folie dient. Aber nach dem erscheinen und den reden des geistes war eben das stück nicht mehr zu steigern und mit dem ersten Akt schliefst auch seine drastische gewalt. Es ist also der erste akt zu einem in der tat unmöglichen drama, und weun man ein werk so stückweise beurteilen dürfte, der gipfel der shakespearischen poesie hier erreicht. Die übelstände aber, welche vom zweiten akt an sichtbar werden, sind folgende. Man empfindet jetzt erst, dafs der tragische gipfel der ganzen handlung hinter uns liegt, und was sonst in Shakespeare's werken auf uns so unwiderstehlich zu wirken pflegt, ist hier, anstatt an uns heranzukommen, vielmehr vorausgesetzt. Der dramatische knoten des stücks ist hier der ermordete vater des helden. Nachdem aber der geist dieses schauderhafte ereignis erzählt hat, ist für die bühne nichts mehr nachzuholen" (Moritz Rapp, Hamlet-Übers., Einleitung).

Auf grund dieser darlegung wiederhole ich, dafs der folgende text mir eine wirkliche einheit zu bilden scheint. Ich 
behaupte also, dafs das stïck in dieser neuen form uns vom ersten bis zum letzten wort in spannung erhält und mit sich fortreilst.

Warum ich die Shakespeare-texte in prosaform drucke, darüber habe ich schon Unser Shakespeare III, s. 65 ff. gesprochen. Es wird niemanden einfallen zu bezweifeln, dals poesie poesie bleibt, auch wenn sie nicht in abgesetzten zeilen gedruckt wird; andrerseits bin ich mit Emerson überzeugt, dafs der rhythmus der poesie Shakespeares erst und nur dann zum vorschein kommt, wenn man die worte des dichters streng sinngemäls liest.

\section{Scene I.}

Enter two sentinels.

1. Stand! who is that?

2. 'Tis $\mathrm{I}$.

1. 0, you come most carefully upon your watch.

2. And if you meet Marcellus and Horatio, the partners of my watch, bid them make haste.

1. I will. See who goes there?

Enter Horatio and Marcellus.

Hor. Friends to this ground.

Mar. And liegemen to the Dane. 0 - farewell, honest soldier: Who hath relieved you?

1. Bernardo hath my place. Give you good night.

Mar. Holla! Bernardo!

2. Say, is Horatio there?

Hor. A piece of him.

2. Welcome, Horatio; welcome, good Marcellus.

Mar. What, hath this thing appeared again to-night?

2. I have seen nothing.

Mar. Horatio says, 'tis but our fantasy, and will not let belief take hold of him touching this dreaded sight, twice seen by us: therefore, I have entreated him along with us to watch the minutes of this night; that if again this apparition come, he may approve our eyes and speak to it.

Hor. Tut, 'twill not appear.

2. Sit down, I pray; and let us once again assail your ears that are so fortified what we have two nights seen.

Hor. Well, sit we down, and let us hear Bernardo speak of this.

2. Last night of all, when yonder star that's westward from the pole had made his course to illumine that part of heaven where now it burns, the bell then tolling one, - 


\section{Enter Ghost.}

Mar. Break off your talk; see where it comes again!

2. In the same figure, like the king that's dead.

Mar. Thou art a scholar; speak to it, Horatio.

2. Looks it not like the king?

Hor. Most like: it horrors me with fear and wonder.

2. It would be spoke to.

Mar. Question it, Horatio.

Hor. What art thou that thus usurps ') the state in which the majesty of buried Denmark did sometimes walk? by heaven, I charge thee, speak !

\section{Exit Ghost.}

Mar. It is offended.

2. See, it stalks away!

Hor. Stay! speak, speak! by heaven, I charge thee, speak!

Mar. 'Tis gone, and makes no answer.

2. How now, Horatio! you tremble and look pale: is not this something more than fantasy? What think you on't?

Hor. Afore my God, I might not this believe without the sensible and true avouch of my own eyes.

Mar. Is it not like the king?

Hor. As thou art to thyself: such was the very armour he had on when he the ambitious Norway combated; so frowned he once, when, in an angry parle, he smote the sledded ${ }^{2}$ ) pole-axe ${ }^{3}$ ) on the ice. 'Tis strange.

Mar. Thus twice before, and jump at this dead hour, with martial stalk he passed through our watch.

Hor. In what particular to work I know not, but, in the thought and scope of my opinion, this bodes some strange eruption to the state.

Mar. Good now, sit down, and tell me, he that knows, why this same strict and most observant watch so nightly toils the subject of the land, and why such daily cost of brazen cannon, and foreign mart for implements of war; why such impress of shipwrights, whose sore task does not divide the sunday from the week; what might be toward, that this sweaty march doth make the night joint-labourer with the day: who is't that can inform me?

Hor. Marry, that can I; at least, the whisper goes so: our late king, who, as you know, was by Fortinbras of Norway - thereto pricked on by a most emulous cause - dared to the combat; in which our valiant Hamlet - for so this side of our known world esteemed him - did slay this Fortinbras; who, by a seal compact, ${ }^{4}$ ) well ratified by law and heraldry, did forfeit, with his life, all those his lands which he stood seized of, by the conqueror: against the which a moiety competent was gaged by our king. Now, sir, young Fortinbras, of inapproved mettle hot and full, hath in the skirts of Norway, here and there, sharked up a sight of lawless
1) $=$ 3. person
s) $=$ sledged
3) Q pollax
4) $Q$ a seale compact. 
resolutes, for food and diet, to some enterprise that hath a stomach in't: and this, I take it, is the chief head and ground of this our watch.

\section{Enter the Ghost.}

But lo, behold! see where it comes again! I'll cross it, though it blast me. Stay, illusion! If there be any good thing to be done, that may do ease to thee and grace to me, speak to me! If thou art privy to thy country 's fate, which, haply, foreknowing may prevent, 0 , speak to me! Or if thou hast extorted in thy life, or hoarded treasure in the womb of earth, for which, they say, you spirits oft walk in death, speak to me! Stay, and speak! speak! Stop it, Marcellus.

\section{2. 'Tis here!}

\section{Exit Ghost.}

Hor. 'Tis here!

Mar. 'Tis gone. 0 we do it wrong, being so majestical, to offer it the show of violence; for it is, as the air, invulnerable, ${ }^{1}$ ) and our vain blows malicious mockery.

2. It was about to speak, when the cock crew.

Hor. And then it faded like a guilty thing upon a fearful summons. I have heard, the cock, that is the trumpet to the morning, doth with his early and shrill-crowing throat awake the god of day; and, at his sound, whether in earth or air, in sea or fire, the stravagant and erring spirit hies to his confines: and of the truth hereof this present object made probation.

Mar. It faded on the crowing of the cock. Some say that ever gainst that season comes wherein our Saviour 's birth is celebrated, the bird of dawning singeth all night long; and then, they say, no spirit dare walk abroad; the nights are wholesome; then no planet frikes, ${ }^{2}$ ) no fairy takes, nor witch hath power to charm, so gracious and so hallowed is that time.

Hor. So have I heard and do in part believe it. But, see, the sun, in russet mantle clad, walks o'er the dew of yon high mountain top: break we our watch up; and by my advice, let us impart what we have seen to-night unto young Hamlet; for, upon my life, this spirit, dumb to us, will speak to him. Do you consent we shall acquaint him with it, as needful in our love, fitting our duty?

Mor. Let's do it, I pray; and I this morning know where we shall find him most conveniently.

\section{Scene II.}

Enter King, Quecn, Hamlet, Leartes, Corambis, and the two Ambassadors, with Attendants.

King. Lords we here have writ to Fortinbras, nephew to old Norway, who, impotents) and bed-rid, scarcely hears of this his nephew's purpose:

1) $\mathbf{Q}$ invelmorable $\left.\quad{ }^{2}\right)=$ 'to move briskly' cp. NED. The planet ventures on an excursion of his own. $\quad$ s) $Q$ impudent. 
and we here dispatch joung good Cornelius, ${ }^{1}$ ) and you, Voltemar, for bearers of these greetings to old Norway; giving to you no further personal power to business with the king, than those related articles do show. Farewell, and let your haste commend your duty.

Gent. ${ }^{2}$ ) In this and all things will we show our duty.

King. We doubt nothing; heartily farewell. And now, Leartes, what's the news with you? You said you had a suit; what is't, Leartes?

Lear. My gracious lord, your favourable licence, now that the funeral rites are all performed, I may have leave to go again to France; for though the favour of your grace might stay me, yet something is there whispers in my heart, which makes my mind and spirits bend all for France.

King. Have you your father's leave, Leartes?

Cor. He hath, my lord, wrung from me a forced grant; and I beseech you, grant, your highness, leave.

King. With all our heart; Leartes, fare thee well.

Lear. I in all love and duty take my leave.

Exit.

King. And now, princely son Hamlet, what means these sad and melancholy moods? For your intent, going to Wittenberg, we hold it most nnmeet and unconvenient, being the joy and half heart of your mother: therefore, let me entreat you stay in court, all Denmark's hope, our cousin, and dearest son.

Ham. My lord, 'tis not the sable suit I wear, no, nor the tears that still stand in my eyes, nor the distracted haviour in the visage, nor all together, mixed with outward semblance, is equal to the sorrow of my heart: him have I lost; I must, of force, forego: these, but the ornaments and suits of woe.

King. This shows a loving care in you, son Hamlet: but you must think, your father lost a father; that father dead lost his, and so shall be until the general ending: therefore, cease laments: it is a fault gainst heaven, fault gainst the dead, a fault gainst nature, and in reason's common course most certain, none lives on earth but he is born to die.

Queen. Let not thy mother lose her prayers, Hamlet; stay here with us, go not to Wittenberg.

Ham. I shall in all my best obey you, madam.

King. Spoke like a kind and a most loving son: and there's no health the king shall drink to-day, but the great cannon to the clouds shall tell the rouse the king shall drink unto prince Hamlet.

Exeunt. ${ }^{\text {) }}$

\section{Scene III.}

Ham. 0, that this too much grieved and sallied flesh would melt to nothing! Or that the universal globe of heaven would turn all to a chaos! 0 God! within two months! No, not two. Married! mine uncle.

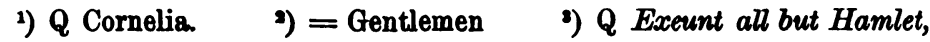
but it is obvious that a new scene (in the evening!) must begin. 
0 , let me not think of it! my father's brother: but no more like my father than I to Hercules. Within two months! Ere yet the salt of most unrighteous tears had left their flushing in her galled eyes - she married! 0 God, a beast, devoid of reason, would not have made such speed: frailty, thy name is woman! Why, she would hang on him, as if increase of appetite had grown by what it looked on. 0, wicked, wicked speed, to make such dexterity to incestuous sheets! Ere yet the shoes were old the which she followed my dead father's corse, like Niobe, all tears: Married! Well, it is not nor it cannot come to good: but break my heart, for I must hold my tongue.

\section{Enter Horatio and Marcellus. $\left.{ }^{1}\right)$}

Hor. Health to your lordship! myself.

Ham. I am very glad to see you: Horatio, - or I much forget

Hor. The same, my lord, and your poor servant ever.

Ham. 0, my good friend! I change that') name with you : but what make you from Wittenberg, Horatio? Marcellus?

Mar. My good lord.

Ham. I am very glad to see you; good even, sirs. But what is your affair in Elsinore? We 'll teach you to drink deep ere you depart.

Hor. A truant disposition, my good lord.

Ham. Nor shall you make me truster of your own report against yourself, sir: I know you are no truant. But what is your affair in Elsinore?

Hor. My good lord, I came to see your father's funeral.

Ham. 0, I pray thee, do not mock me, fellow-student; I think it was to see my mother's wedding.

Hor. Indeed, my lord, it followed hard upon.

Ham. Thrift, thrift, Horatio! the funeral baked-meats did coldly furnish forth the marriage tables. Would I had met my dearest foe in heaven ere ever I had seen that day, Horatio. 0 my father! methinks I see my father.

Hor. Where, my lord?

Ham. Why; in my mind's eye, Horatio.

Hor. I saw him once; he was a gallant king.

Ham. He was a man; take him for all in all; I shall not look upon his like again.

Hor. My lord, I think I saw him yesternight.

Ham. Saw? who?

Hor. My lord, the king, your father.

Ham. The king? my father? he? ') you?

Hor. Season your admiration for a while with an attentive ear, till I may deliver, upon the witness of these gentlemen, this wonder to you.

Ham. For God's love, let me hear it.
1) Also Bernardo.
צ) accented.
8) $Q$ ke ( $Q$ the king my father ke you). 
Hor. Two nights together had these gentlemen, Marcellus and Bernardo, on their watch, in the dead vast and middle of the night, been thus encountered by a figure like your father, armed to point, exactly, cap-a-pe, appears before them thrice: he walks before their weak and fearoppressed eyes within his truncheon's length; while they, distilled almost to jelly with the act of fear, stand dumb and speak not to him. This to me in dreadful secrecy impart they did; and 1 with them the third night kept the watch; where as they had delivered, form of the thing, each part made true and good, the apparition comes: I knew your father; these hands are not more like.

Ham. 'Tis very strange.

Hor. As I do live, my honoured lord, 'tis true: and we did think it right done in our duty to let you know it.

Ham. Where was this?

Mar. My lord, upon the platform where we watched.

Ham. Did you not speak to it?

Hor. My lord, we did; but answer made it none: yet once methought it was about to speak and lifted up his head to motion, like as he would speak: but even then the morning cock crew loud, and, in all haste, ${ }^{1}$ ) it shrunk in haste ${ }^{2}$ ) away, and vanished our sight. to-night?

Ham. Indeed, indeed, sirs, but this troubles me. Hold you the watch

All. We do, my lord.

Ham. Armed, say ye?

All. Armed, my good lord.

Ham. From top to toe?

All. My good lord, from head to foot.

Ham. Why, then saw you not his face?

Hor. 0 yes, my lord, he wore his beaver up.

Ham. How looked he? Frowningly?

Hor. A countenance more in sorrow than in anger.

Ham. Pale or red?

Hor. Nay, very pale.

Ham. And fixed his eyes upon you?

Hor. Most constantly.

Ham. I would I had been there.

Hor. It would have much amazed you.

Ham. Yea, very like, very like. Staid it long?

Hor. While one with moderate pace might tell a hundred.

Marc. 0, longer, longer.

Ham. His beard was grizzled, - no?

Hor. It was as I have seen it in his life, a sable silver.

Ham. I will watch to-night; perchance, 'twill walk again.

Hor. I warrant it will.

Ham. If it assume my noble father's person, I'll speak to it if hell itself should gape and bid me hold my peace. Gentlemen, if you have
1) = showing excitement
$\left.{ }^{2}\right)=$ very quickly 
hither concealed this sight, let it be tenable in your silence still; and whatsoever else shall chance to-night, give it an nnderstanding, but no tongue: I will requite your loves. So, fare you well: upon the platform 'twixt eleven and twelve I'll visit you.

All. Our duties to your honour.

Exeunt.

Ham. 0, your loves, your loves, as mine to you: farewell. My father's spirit! in arms! Well, all's not well; I doubt some foul play: would the night were come! Till then sit still, my soul: foul deeds will rise, though all the world o'erwhelm them, to men's eyes.

Exit.

\section{Scene IV.}

\section{Enter Leartes and Ofelia.}

Lear. My necessaries are embarked; I must aboard: but ere I part, mark what I say to thee. I see prince Hamlet makes a show of love; beware, Ofelia! do not trust his vows. Perhaps, he loves you now; and now his tongue speaks from his heart; but yet take heed, my sister: the chariest maid is prodigal enough, if she unmask her beanty to the moon: virtue itself scapes not calumnious thoughts; believe it, Ofelia! Therefore, keep aloof! lest that he trip thy honour and thy fame.

Ofelia. Brother, to this I have lent attentive ear, and doubt not but to keep my honour firm: but, my dear brother, do not you, like to a cunning sophister, teach me the path and ready way to heaven, while you, forgetting what is said to me, yourself, like to a careless libertine, doth give his heart his appetite at full, and little recks how that his houour dies.

Lear. No, fear it not, my dear Ofelia. Here comes my father: occasion smiles upon a second leave.

\section{Enter Corambis.}

Cor. Yet here, Leartes? aboard, aboard, for shame! The wind sits in the shoulder of your sail, and you are staid for. There; my blessing with thee; and these few precepts in thy memory. Be thou familiar, but by no means vulgar. Those friends thou hast and their adoptions tried, grapple them to thee with a hoop of steel; but do no dull the palm with entertain of every new unfledged courage. ${ }^{1}$ ) Beware of entrance into a quarrel; but being in, hear it that the opposed may beware of thee. Costly thy apparel as thy purse can buy; but not expressed in fashion; for the apparel oft proclaims the man, and they of France, of the chief rank and station, are, of a most, ${ }^{2}$ ) select and general; chief in that. ${ }^{3}$ ) This above all : to thy own self be true, and it must follow, as the night the day, thou canst not then be false to any one. Farewell; my blessing with thee.

Lear. I humbly take my leave. Farewell, Ofelia; and remember well what I have said to you.

Exit.

1) = hope and joy combined; enthusiasm.

?) = in regard to the majority of things.

s) = but in regard to apparel they hold undoubtedly the first place. 
Ofelia. It is already locked within my heart, and you yourself shall keep the key of it.

Cor. What is't, Ofelia, he hath said to you?

Ofelia. Something touching the prince Hamlet.

Cor. Marry, well thought on: 'tis given me to understand that you have been too prodigal of your maiden presence unto prince Hamlet: if it be so - as so 'tis given to me, and that in way of caution - I must tell you, you do not understand yourself so well as befits my honour and your credit.

Ofelia. My lord, he hath made many tenders of his love to me.

Cor. Tenders! ay; ay, tenders you may call them.

Ofelia. And withal such earnest vows.

Cor. Springes, to catch woodcocks. What, do not I know, when the blood doth burn, how prodigal the tongue lends the heart vows! In brief: be more scanter of your maiden presence; or tendring thus you 'll tender me a fool.

Ofelia. I shall obey, my lord, in all I may.

Cor. Ofelia, receive none of his letters; for lovers' lines are snares to entrap the heart: refuse his tokens; both of them are keys to unlock chastity unto desire. Come in, Ofelia: such men often prove great in their words, but little in their love.

Ofelia. I will, my lord.

Exeunt.

\author{
Scene V. \\ Enter Hamlet, Horatio, and Marcellus.
}

Ham. The air bites shrewd; it is an eager and a ${ }^{1}$ ) nipping wind. What hour is't?

Hor. I think it lacks of twelve.

Mar. No, 'tis struck.

Sound trumpets.

Hor. Indeed? I heard it not. What does this mean, my lord?

Ham. O, the king doth wake to-night and takes his rouse, keeps ${ }^{\text {) }}$ wassail, and the swaggering up-spring reels; and, as he drains ${ }^{3}$ ) his dranghts of Rhenish down, the kettle, drum, ${ }^{4}$ ) and trumpet thus bray out the triumphs of his pledge.

Hor. Is it a custom here?

Ham. Ay, marry, is't : and though I am native here and to the manner born, it is a custom more honoured in the breach than in the observance.

\title{
Enter the Ghost.
}

Hor. Look, my lord, it comes!

Ham. Angels and ministers of grace defend us! Be thou a spirit of heslth, or goblin damned, bring with thee airs from heaven, or blasts from hell, be thy intents wicked or charitable, thou comest in such
1) $\mathbf{Q}$ an
9) $\mathbf{Q}$ keep
s) $Q$ dreams
๖) $Q$ kettle, drumme 
questionable shape that I will speak to thee: I'll call thee Hamlet, king, father, royal Dane: 0 , answer me! Let me not burst in ignorance; but say why thy canonised bones, hearsed in death, have burst their ceremonies; why thy sepulchre, in which we saw thee quietly interred, hath burst his ponderous and marble jaws, to cast thee up again. What may this mean, that thou, dead corse, again, in complete steel, revisits thus the glimpses of the moon; making night hideous, and we fools of nature so horridly to shake our disposition with thoughts beyond the reaches of our souls! Say! speak! wherefore? what may this mean? you alone.

Hor. It beckons you, as though it had something to impart to

Mar. Look, with what courteous action it waves you to a more removéd ground: but do not go with it.

Hor. No, by no means, my lord.

Ham. It will not speak; then will I follow it.

Hor. What if it tempt you toward the flood, my lord, that buckles ${ }^{1}$ ) o'er his base into the sea, and there assume some other horrible shape, which might deprive your sovereignty of reason and drive you into madness? think of it.

Ham. Still am I called. Go on: I'll follow thee.

Hor. My lord, you shall not go.

Ham. Why, what should be the fear? I do not set my life at a pin's fee; and for my soul, what can it do to that, being a thing immortal like itself? Go on: I'll follow thee.

Mar. My lord, be ruled: you shall not go.

Ham. My fate cries out, and makes each petty artire ${ }^{2}$ ) as hardy as the Nemean lion's nerve. Still am I called. Unhand me, gentlemen! By heaven, I'll make a ghost of him that lets me! away, I say! Go on: I'll follow thee.

\section{Scene VI. Enter Corambis and Montano.}

Cor. Montano, here these letters to my son, and this same money with my blessing to him: and bid him ply his learning, good Montano.

Mon. I will, my lord.

\section{Enter Ofelia.}

Exit.

Cor. Farewell. How now, Ofelia! what's the news with you?

Ofelia. $0 \mathrm{my}$ dear father! such a change in nature, so great an alteration in a prince, so pitiful to him, fearful to me, a maiden's eye ne'er looked on.

Cor. Why, what's the matter, my Ofelia?

Ofelia. 0, young prince Hamlet, the only flower of Denmark, he is bereft of all the wealth he had; the jewel that adorned his feature most

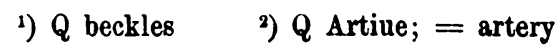


is filched and stolen away; his wit's bereft him. He found me walking in the gallery, all alone: there comes he to me, with a distracted look, his garters lagging down, his shoes untied, and fixed his eyes so steadfast on my face, as if they had vowed this is their latest object. Small while he stood, but gripes me by the wrist, and there he holds my pulse, till, with a sigh, he doth unclasp his hold, and parts away, silent, as is the mid-time of the night: and as he went his eye was still on me, for thus his head over his shoulder looked; he seemed to find the way without his eyes; for out of doors he went without their help; and so did leave me. of late?

Cor. Mad for thy love. What, have you given him any cross words

Ofelia. I did repel his letters, deny his gifts, as you did charge me.

Cor. Why, that hath made him mad. By heaven, 'tis as proper for our age to cast beyond ourselves, as 'tis for the younger sort to leave their wantonness. Well, I am sorry that I was so rash: but what remedy? Let's to the king: this madness may prove, though wild awhile, yet more true to thy love.

\section{Exeunt.}

\section{Scene VII.}

\section{Enter King and Queen, Rossencraft and Guilderstone.}

King. Right noble friends, that our dear cousin Hamlet lath lost the very heart of all his sense - it is most right, and we most sorry for him: therefore we do desire, even as you tender our care to him and our great love to you, that you will labour but to wring from him the cause and ground of his distemperancy. Do this; the king of Denmark shall be thankful.

Ross. My lord, whatsoever lies within our power your majesty may more command in words than use persuasions to your liegemen, bound by love, by duty, and obedience.

Guil. What we may do for both your majesties to know the grief troubles the prince, your son, we will endeavour all the best we may: so, in all duty, do we take our leave.

King. Thanks, Guilderstone and gentle Rossencraft.

Queen. Thanks, Rossencraft and gentle Guilderstone.

\section{Enter Corambis and Ofelia. ${ }^{1)}$}

Cor. My lord, the ambassadors are joyfully returned from Norway.

King. Thou still hast been the father of good news.

Cor. Have I, my lord? I assure your grace, I hold my duty as I hold my life, both to my God and to my sovereign king: and I believe, or else this brain of mine hunts not the train of policy so well as it had wont to do, but I have found the very depth of Hamlet's lunacy.

Queen. God grant, he hath.

1) Of course 'Exeunt Rossencraft and Guilderstone'. 


\section{Enter the Ambassadors.}

King. Now, Voltemar, what from our brother Norway?

Volt. Most fair return of greetings and desires. Upon our first he sent forth to suppress his nephew's levies, which to him appeared to be a preparation gainst the Polack; but better looked into, he truly found it was against your highness: whereat grieved, that so his sickness, age, and impotence was falsely born in hand, sends out arrests on Fortinbras; which he, in brief, obeys; receives rebuke from Norway, and in fine makes vow before his uncle never more to give the assay of arms against your majesty. Whereon old Norway, overcome with joy, gives him three thousand crowns in annual fee, and his commission to employ those soldiers, so levied as before against the Polack: with an entreaty, herein further shown, that it would please you to give quiet pass through your dominions for that enterprise, on such regards of safety and allowances as therein are set down.

King. It likes us well, and at fit time and leisure we'll read and answer these his articles. Meantime we thank you for your well-took labour: go to your rest; at night we'll feast together. Right welcome home!

\section{Exeunt Ambassadors.}

Cor. This business is very well despatched. Now, my lord, touching the young prince Hamlet, certain it is that he is mad; mad let us grant him then. Now to know the cause of this effect -

Queen. Good my lord, be brief.

Cor. Madam, I will. My lord, I have a daughter, bave while she's mine: for that we think is surest, we often lose. Now to the prince: my lord, but note this letter the which my daughter in obedience delivered to my hands.

King. Read it, my lord.

Cor. Mark, my lord.

Doubt that in earth is fire;

Doubt that the stars do move;

Doubt truth to be a liar

But do not doubt I love.

To the beautiful Ofelia.

Thine ever the most unhappy prince Hamlet.

My lord, what do you think of me? ay, or what might you think when I saw this?

King. As of a true friend and a most loving subject.

Cor. I would be glad to prove so. Now when I saw this letter, thus I bespake my maiden: lord Hamlet is a prince, out of your star, and one that is unequal for your love: therefore I did command her refuse his letters, deny his tokens, and to absent herself. She as my child obediently obeyed me. Now since which time, seeing his love thus crossed - which I took to be idle and but sport - he straightway grew into a melancholy, from that unto a fast, then unto distraction, then into a sadness, from that unto a madness, and so, by continuance and weakness of the brain, into this frenzy which now possesseth him: and if this be not true, take this from this. 
King. Think you, 'tis 80 ?

Cor. How so, my lord? I would very fain know that thing that I have said 'tis so' positively, and it hath fallen out otherwise. Nay, if circumstances lead me on, I'll find it out, if it were hid as deep as the centre of the earth.

King. How should we try this same?

Cor. Marry, my good lord, thus. The prince's walk is here in the gallery; there let Ofelia walk until he comes: yourself and I will stand close in the study: there shall you hear the effect of all his heart; and if it prove any otherwise than love, then let my censure fail another time.

King. See where he comes, poring upon a book.

\section{Enter Hamlet.}

Cor. Madam, will it please your grace to leave us here?

Queen. With all my heart.

Exit.

Cor. And here, Ofelia, read you on this book; and walk aloof, the king shall be unseen. ${ }^{1}$ )

Ofelia. My lord, I have sought opportunity, which now I have, to redeliver to your worthy hands a small remembrance; such tokens which I have received of you.

Ham. I never gave you nothing.

Ofelia. My lord, you know right well you did; and with them such earnest vows of love as would have moved the stoniest breast alive: but now too true I find, - rich gifts wax poor when givers grow unkind.

Ham. I never loved you.

Exit.

Ofelia. Great God of heaven, what a quick change is this! The courtier, scholar, soldier, all in him, all dashed and splintered thence. 0 , woe is me, to have ${ }^{2}$ ) seen what $I$ have seen, see what I see.

\section{Scene VIII.}

\section{Enter Corambis, Guilderstone and Rossencraft. ${ }^{3}$ )}

Cor. You seek prince Hamlet; see, there he is.

Guil. Health to your lordship.

Exit.

Ham. What! Guilderstone and Rossencraft! Welcome, kind schoolfellows, to Elsinore!

Guil. We thank your grace, and would be very glad you were as when we were at Wittenberg.

Ham. I thank you: but is this visitation free? of yourselves? or

1) Exeunt King and Corambis.

2) $\mathbf{Q} \mathbf{a}$

3) Q Enter Corambis .... Enter Guilderstone and Rossencraft. Apparently this scene is laid on the platform and Hamlet, at the beginning, is discovered looking towards the sea. 
were you not sent for? Tell me true. Come, I know the good king and queen sent for you. There is a kind of confession in your eye: come, I know you were sent for.

Guil. What say ') you!

Ham. Nay, then I see how the wind sits. Come, you were sent for.

Ross. My lord, we were, and willingly; if we might know the cause and ground of your discontent.

Ham. Why, I want preferment.

Ross. I think not so, my lord.

Ham. Yes, faith: this great world, you see, contents me not; no, nor the spangled heavens, nor earth, nor sea; no, nor man that is so glorious a creature contents not me; no, nor woman too, though you laugh.

Guil. My lord, we laugh not at that.

Ham. Why did you laugh then when I said man did not content me?

Guil. My lord, we laughed when you said man did not content you, what entertainment the players shall have? they are coming to you.

\section{Enter Corambis and players. $\left.{ }^{2}\right)$}

Ham. Welcome, masters; welcome, all. I pray, my lord, will you see the players well bestowed.

Cor. My lord, I will use them according to their deserts.

Ham. 0, far better, man: use every man after his deserts, then who should scape whipping? Use them after your own honour and dignity, the less they deserve, the greater credit's yours.

Cor. Welcome, good fellows.

Exit.

Ham. Gentlemen, for your kindness I thank you; and for a time I would desire you leave me.

Guil. Our love and duty is at your command.

Exeunt.

\section{Scene IX. \\ Enter the King, Queen, and Lords.}

King. Lords, can you by no means find the cause of our son Hamlet's lunacy? You being so near in love, even from his youth, methinks should gain more than a stranger should.

Guil. My lord, we have done all the best we could to wring from him the cause of all his grief: but still he puts us off, and by no means would make an answer to that we exposed.

Ross. Yet was he something more inclined to mirth before we left him, and, I take it, he hath given order for a play to-night at which he craves your highness' company.

King. With all our heart; it likes us very well. Gentlemen, seek still to increase his mirth; spare for no cost, our coffers shall be open, and we unto yourselves will still be thankful.

1) accented

2) Q The Trumpets sound, Enter Carambis ... Enter players. 
Both. In all we can, be sure, you shall command.

Queen. Thanks, gentlemen; and what the queen of Denmark may pleasure you, be sure, you shall not want.

Guil. We'll once again unto the noble prince.

King. Thanks to you both. ${ }^{1}$ ) Gertrude, you'll see this play?

Queen. My lord, I will; and it joys me at the soul, he is inclined to any kind of mirth.

Cor. Madam, I pray, be ruled by me: and, my good sovereign, give me leave to speak. We cannot yet find out the very ground of his distemperance; therefore I hold it meet - if so it please you; else they shall not meet - and thus it is: -

King. What is 't, Corambis?

Cor. Marry; my good lord, this: soon when the sports are done, madam, send you in haste to speak with him: and I myself will stand behind the arras. There question you the canse of all his grief: and then, in love and nature unto you, he'll tell you all. My lord, how think you on't?

King. It likes us well; Gertrude, what say you?

Queen. With all my heart soon will I send for him.

Cor. Myself will be that happy messenger who hopes his grief will be revealed to her.

Exeunt omnes.

\section{Scene X.}

Enter King, Queen, Corambis, and other lords. ${ }^{2}$ )

King. How now, son Hamlet, how fare you? shall we have a play? Ham. Ay, father.

Enter the Duke and Duchess.

Duke. Full forty years are passed, their date is gone, Since happy time joined both our hearts as one: And now the blood that filled my youthful veins Runs weakly in their pipes; and all the strains Of music, which whilom pleased mine ear, Is now a burthen that age cannot hear: And therefore, sweet, nature must pay his due; To heaven must $I$, and leave the earth with you.

Duchess. 0, say not so! lest that you kill my heart: When death takes you, let life from me depart!

Duke. Content thyself; when ended is my date Thou mayst, perchance, have a more noble mate, More wise, more youthful, and one -

Duchess. 0, speak no more! for then am I accursed; None weds the second but she kills the first:

1) Of course, 'Exeunt Rossencraft and Guilderstone'.

9) Hamlet is expecting his guests and it is obvious that he must be imagined to converse with Rossencraft and Guilderstone. 
A second time I kill my lord that's dead

When second husband kisses me in bed.

Duke. I do believe you, sweet, what now you speak;

But what we do determine oft we break:

For our demises still are overthrown,

Our thoughts are ours, their end's none of our own:

So think you will no second husband wed,

But die thy thoughts when thy first lord is dead.

Duchess. Both here and there pursue me lasting strife,

If, once a widow, ever I be wife.

Duhe. 'Tis deeply sworn: sweet, leave me here awhile.

My spirits grow dull, and fain would I beguile

The tedious time with sleep.

Duchess.

Sleep rock thy brain,

And never come mischance between us twain.

Exit Lady.

Ham. Madam, how do you like this play?

Queen. The lady protests too much.

Ham. 0, but she'll keep her word.

King. Have you heard the argument? Is there no offence in it? What do you call the name of the play ${ }^{1}$ )?

Ham. This play is the image of a murder done in Gayana.

Murd.2) Thoughts black, hands apt, drugs fit, and time agreeing;

Confederate season, else no creature seeing;

Thou mixture rank, of midnight weeds collected,

With Hecate's bane thrice blasted, thrice infected,

Thy natural magic and dire property

One wholesome life usurps immediately.

Cor. The king rises; lights, ho!

Exit.

Exeunt king and lords. $\left.{ }^{3}\right)$

Ham. My mother! she') hath sent to speak with me! 0 God, let ne'er the heart of Nero euter this soft bosom! Let me be cruel, not unnatural. I will speak daggers: those sharp words being spent, to do her wrong my soul shall ne'er consent.

Exit.

\section{Scene XI. \\ Enter the King.}

King. O that this wet that falls upon my face would wash the crime clear from my conscience! When I look up to heaven I see my tresspass; the earth doth still cry out upon my fact pay me the murder of a brother and a king, and the adulterous fault I have committed! 0 , these are sins that are unpardonable. Why; say thy sins were blacker than is jet, yet

1) $Q$ phy ') = murderer ') Of course the Queen too. 4) accented. Anglia. N. b. XVIII. 
may contrition make them as white as snow. Ay; but still to persever in a sin, it is an act gainst the universal power. Most wretched man! stoop, bend thee to thy prayer; ask grace of heaven to keep thee from despair.

\section{He kneels. Enters Hamlet.}

Ham. Ay, so: come forth, and work thy last! and thus he dies; and so am I revenged. No: get thee up again. When he's at game, swearing, taking his carouse, drinking drunk, or in the incestuous pleasure of his bed - then trip him that his heels may kick at heaven and fall as low as hell! My mother stays: this physic but prolongs thy weary days.

Exit Hamlet.

King. My words fly up, my sins remain below: no king on earth is safe, if God's his foe.

Exit King.

\section{Scene XII.}

\section{Enter Queen and Corambis.}

Cor. Madam, I hear young Hamlet coming: I'll shroud myself behind the arras.

Ham. How is't with you, mother?

Exit Corambis.

Queen. How is't with you?

Ham. I'll tell you; but first we'll make all safe. ${ }^{1}$ )

Queen. Hamlet, thou hast thy father much offended.

Ham. Mother, you have my father much offended.

Queen. How now, boy!

Ham. How now, mother! Come here, sit down; for you shall hear me speak.

Queen. What wilt thou do? thou wilt not murder me! Help, ho!

Cor. Help for the queen!

Ham. Ay, a rat? dead, for a ducat!

Queen. Hamlet, what hast thou done?

Haml. Not so much harm, good mother, as to kill a king and marry with his brother.

Queen. How? kill a king?

Ham. Ay, a king: nay, sit you down; and ere you part, if you be made of penetrable stuff, I'll make your eyes look down into your heart, and see how horrid there and black it shows.

Queen. Hamlet, what meanest thon by these killing words?

Ham. Why, this I mean: see here, behold this picture: it is the portraiture of your deceaséd husband; see here a face, to outface Mars himself; an eye, at which his foes did tremble at; a front wherein all virtues are set down for to adorn a king, and guild his crown: whose heart went hand in hand even with that vow he made to you in marriage; and

1) Hamlet locks the door. 
he is dead! murdered! damnably murdered! This was your husband: look you now, here is your husband: with a face like Vulcan! a look fit for a murder and a rape; a dull, dead, hanging look, and a hell-bred eye, to affright children and amaze the world: and this same have you left to change with this! What devil thus hath cozened you at hob-man-blind? Ah! have you eyes, and can you look on him that slew my father, and your dear husband, to live in the incestuous pleasure of his bed?

Queen. Alas, it is the weakness of thy brain which makes thy tongue to blazon thy heart's grief. But as I have a soul, I swear by heaven, I never knew of this most horrid murder: but, Hamlet, this is only fantasy; and, for my love, forget these idle fits.

Ham. Idle? no, mother: my pulse doth beat like yours; it is not madness that possesseth Hamlet. 0 mother, if ever you did my dear father love, forbear the adulterous bed to-night, and win yourself by little as you may; in time, it may be, you will loathe him quite. And, mother, but assist me in revenge, and in his death your infamy shall die.

Queen. Hamlet, I vow by that majesty that knows our thoughts, and looks into our hearts: I will conceal, consent, and do my best, what stratagem soe'er thou shalt devise.

Ham. It is enough: mother, good night. ${ }^{\text {) }}$

\section{Enter the King.}

King. Now, Gertrude, what says our son? how do you find him?

Qneen. Alas, my lord, as raging as tbe sea: whenas he came, I first bespake him fair; but then he throws and tosses me about as one forgetting that I was his mother: at last, I called for help; and as I cried, Corambis called; which Hamlet no sooner heard, but whips me out his rapier, and cries 'a rat, a rat!' and, in his rage, the good old man he kills.

King. Why, this his madness will undo our state. ${ }^{2}$ ) Gertrude, your son shall presently to England; his shipping is already furnished; and we have sent by Rossencraft and Guilderstone our letters to our dear brother of England, for Hamlet's welfare and his happiness: haply the air and climate of the country may please him better than this native home. See where he comes. ${ }^{3}$ )

\section{Enter Hamlet.}

Well, son Hamlet, we in care of you, but specially in tender preservation of your health, the which we prize even as our proper self - it is our mind you forthwith go for England: the wind sits fair, you shall aboard to-night; Lord Rossencraft and Guilderstone shall go along with you.

Ham. 0, with all my heart: farewell, mother. ${ }^{4)}$

King. Gertrude, leave me; and take your leave of Hamlet. ${ }^{5}$ ) To England is he gone ne'er to return : our letters are unto the king of England, that on the sight of them, on his allegiance, he, presently, without demanding why, - that Hamlet lose his head; for he must die: there's more in him than shallow eyes can see; he once being dead, why then our state is free.

Exit.

1) Of course 'Exit'. king had sent for Hamlet.
2) The king looks behind the arras. 4) Hamlet 'exit'.
5) Exit Queen. 


\section{Scene XIII.}

Enter Fortinbras, drum, and soldiers. ${ }^{1)}$

Fort. Captain, from us go greet the king of Denmark; tell him that Fortinbras, nephew to old Norway, craves a free pass and conduct over his land according to the articles agreed on. You know the rendez-vous; go. March away.

Exeunt all.

\section{Scene XIV.}

\section{Enter King and Queen.}

King. Hamlet is shipped for England, fare him well!') I hope to hear good news from thence ere long, if every thing fall out to our content, as I do make no doubt but so it shall.

Queen. God grant it may; heavens keep my Hamlet safe! But this mischance of old Corambis' death hath piercéd so the young Ofelia's heart, that she, poor maid, is quite bereft her wits.

King. Alas, dear heart, and on the other side, we understand her brother is come from France; and he hath half the heart of all our land: and hardly he'll forget his father's death, unless by some means he be pacified.

\section{A noise within. Enter Leartes.}

Lear. Stay there until I come. 0 thou vild king, give me my father: speak! say, where's my father?

King. Dead.

Lear. Who hath murdered him? speak! I'll not be juggled with, for he is murdered.

Queen. True; but no by him.

Lear. By whom? By heaven, I'll be resolved.

King. Let him go, Gertrude! away! I fear him not. There's such divinity doth wall a king that treason dares not look on. Let him go, Gertrude. That your father is murdered, 'tis true; and we most sorry for it, being the chiefest pillar of our state: therefore will you, like a most desperate gamester, swoop-stake-like, draw at friend, and foe, and all?

Lear. To his good friends thus wide I'll ope mine arms, and lock them in my heart; but to his foes I will no reconcilement but by blood.

King. Why, now you speak like a most loving son: and that in soul we sorrow for ${ }^{3}$ ) his death yourself ere long shall be a witness; meanwhile be patient, and content yourself.

1) This scene is necessary for the sake of a clear perception of the time that has elapsed since the close of scene XII. The course of events is only twice interrupted (between scene V \& VI and between scene XII \& XIII).

2) Apparently the Queen has just been talking of Hamlet and shown anxiety as to her son's welfare.

3) $Q$ for for. 
Lear. Grief upon grief; my father murdered, my sister thus distracted! cursed be his soul that wrought this wicked act!

King. Content you, good Leartes, for a time. Although I know your grief is as a flood, brimful of sorrow, but forbear a while: and think already the revenge is done on him that makes you such a hapless son.

Lear. You have prevailed, my lord: a while I'll strive to bury grief within a tomb of wrath which, once unhearsed, then the world shall hear, Leartes had a father he held dear.

King. No more of that: ere many days be done, you shall hear that you do not dream upon.

Exeunt omnes.

\section{Scene XV.}

\section{Enter Horatio and the Queen.}

Hor. Madam, your son is safe arrived in Denmark: this letter I even now received of him, whereas he writes how he escaped the danger and subtle treason that the king had plotted. Being crossed by the contention of the winds he found the packet sent to the king of England; wherein he saw himself betrayed to death: as, at his next conversion with your grace, he will relate the circumstance at full.

Queen. Then I perceive there 's treason in his looks that seemed to sugar o'er his villainy: but I will soothe and please him for a time; for murderous minds are always jealous. But know not you, Horatio, where he is?

Hor. Yes, madam; and he hath appointed me to meet him on the east side of the city, to-morrow morning.

Queen. 0 fail not, good Horatio; and withal commend me a mother's care to him. Bid him a while be wary of his presence lest that he fail in that he goes about.

Hor. Madam, never make doubt of that. I think by this the news be come to court, he is arrived: observe the king, and you shall quickly find, Hamlet being here, things fell not to his mind.

Queen. But what became of Guilderstone and Rossencraft?

Hor. He being set ashore, they went for England; and in the packet there writ down that docm to be performed on them, pointed for him:1) and by great chance he had his father's seal; so all was done without discovery.

Queen. Thanks be to heaven for blessing of the prince. Horatio, once again I take my leave, with thousand mother's blessings to my son.

Hor. Madam, adieu. possible.

1) Hamlet was compelled to make the King's position as difficult as 


\section{Scene XVI.}

\section{Enter King and Leartes.}

King. Hamlet from England! is it possible? What chance is this? they are gone, and he come home. ${ }^{1}$ )

Lear. 0 , he is welcome; by my soul, he is! At it my jocund heart doth leap for joy that I shall live to tell him, thus he dies.

King. Leartes, content yourself; be ruled by me: and you shall have no let for your revenge.

Lear. My will, not all the world.

King. Nay; but, Leartes, mark the plot I have laid. I have heard him often with a greedy wish, upon some praise that he hath heard of you touching your weapon, which, with all his heart, he might be once tasked for to try your cunning.

Lear. And how for this?

King. Marry, Leartes, thus: I'll lay a wager, shall be on Hamlet's side, and you shall give the odds (the which will draw him with a more desire to try the mastery) that in twelve venies you gain not three of him. Now, this being granted, when you are hot in midst of all your play, among the foils shall a keen rapier lie, steeped in a mixture of deadly poison, that if it draws but the least dram of blood in any part of him, he cannot live. This being done, will free you from suspicion; and not the dearest friend that Hamlet loved will ever have Leartes in suspect.

Lear. My lord, I like it well: but say lord Hamlet should refuse this match?

King. I'll warrant you, we'll put on you such a report of singularity will bring him on, although against his will: and lest that all should miss I'll have a potion that shall ready stand in all his heat when that he calls for drink shall be his period and our happiness.

Lear. 'Tis excellent. ${ }^{2}$ ) 0 , would the time were come!

Exeunt.

\section{Scene XVII.}

\section{Enter King, Queen, Leartes, Lords. ${ }^{3}$ )}

King. Now, son Hamlet, we have laid upon your head, and make no question but to have the best.

1) Rossencraft and Guilderstone were only companions of the prince and, of course, had no power to stay him from going on land when and where it should please him.

2) It ought to be remembered that Hamlet's mastership in fencing is unquestioned and that Leartes knows that he himself, as easily as his adversary, may lose his life in the affair. The then very common practice of 'fastning your left hand on the hiltes of your enemies swoord' could, at any moment, - as it afterwards actually happened - turn the device of Leartes upon himself. Leartes' action is not at all so cowardly as it may at first appear and is, moreover, amply excused though, of course, not justified by the strange situation in which Leartes finds himself.

) Here also Hamlet may be imagined to be conversing with some lords. 
Ham. Your majesty hath laid on ${ }^{1}$ ) the weaker side.

King. We doubt it not. Deliver them the foils.

Ham. First, Leartes, here's my hand and love, protesting that I never wrouged Leartes: therefore let's be at peace; and think I have shot mine arrow o'er the house and hurt my brother.

Lear. Sir, I am satisfied in nature; but in terms of honour I'll stand aloof, and will no reconcilement till by some elder masters of our time I may be satisfied.

King. Give them the foils.

Ham. I'll be your foil, Leartes. These foils have all a length ? ${ }^{2}$ ) Come on, sir! a hit. ${ }^{\text {) }}$

Lear. No, none.

Ham. Judgment.

Here they play.

Gent. ${ }^{4)}$ A hit; a most palpable hit.

Lear. Well, come again!

Ham. Another. Judgment.

They play again.

Lear. Ay, I grant; a touch, a touch.

King. Here, Hamlet, the king doth drink a health to thee: give him the wine.

Ham. Set it by: I'll have another bout first; I'll drink anon.

Queen. Here, Hamlet, thy mother drinks to thee.

She drinks.

Ham. Leartes, come; you dally with me: I pray you pass with your most cunningst play.

Lear. Ay, say you so? Have at you! I'll hit you now, my lord, And yet it goes almost against my conscience.

Ham. Come on, sir!

They catch one another's rapiers, ${ }^{5}$ ) and both are wounded; Leartes falls down; the Queen falls down and dies.

King. Look to the queen.

Queen. 0 the drink! the drink! Hamlet, the drink!

Hom. Treason? ho, keep the gates!

Lords. How is't, my lord Leartes?

Lear. Even as a coxcomb should, toolishly slain with my own weapon. Hamlet, thou hast not in thee half an hour of life! the fatal instrument is in thy hand, unbated and invenomed. Thy mother's poisoned; that drink was made for thee.

Ham. The poisoned instrument within my hand! Then, venom, to thy venom! Die, damned villain!

The king dies.

1) $Q \mathrm{a}$

2) $Q$ langht behind 'sir'.

s) In $Q$ in italics, as if it were a stage-direction; but a colon is put

4) = gentlemen

5) This is called 'to disarm by the left'. 


\section{EICHHOFF, VERSUCH EINER PRAKTISCHEN HAMLET-KRITIK.}

Lear. 0 , he is justly served. Hamlet, before I die, here take my hand, and withal my love: I do forgive thee.

Ham. And I thee.

Leartes dies.

Hamlet dies.

\section{Enter Voltemar and the Ambassadors from England.}

Enter Fortinbras with his train.

Fort. Where is this bloody sight? 0 imperious death! how many princes hast thou at one draft bloodily shot to death!

Ambass. Our ambassy that we have brought from England, where be these princes that should hear us speak? 0 most most unlooked-for time! unhappy country!

Fort. I have some rights of memory to this kingdom, which now to claim my leisure doth invite me. Let four of our chiefest captains bear Hamlet like a soldier to his grave: for he was likely, had he lived, to have $^{1}$ ) proved most royal. Take up the body: such a sight as this becomes the fields, but here doth much amiss.

1) $Q$ a

Finis.

Charlottenburg.

Theodor EichHoff. 